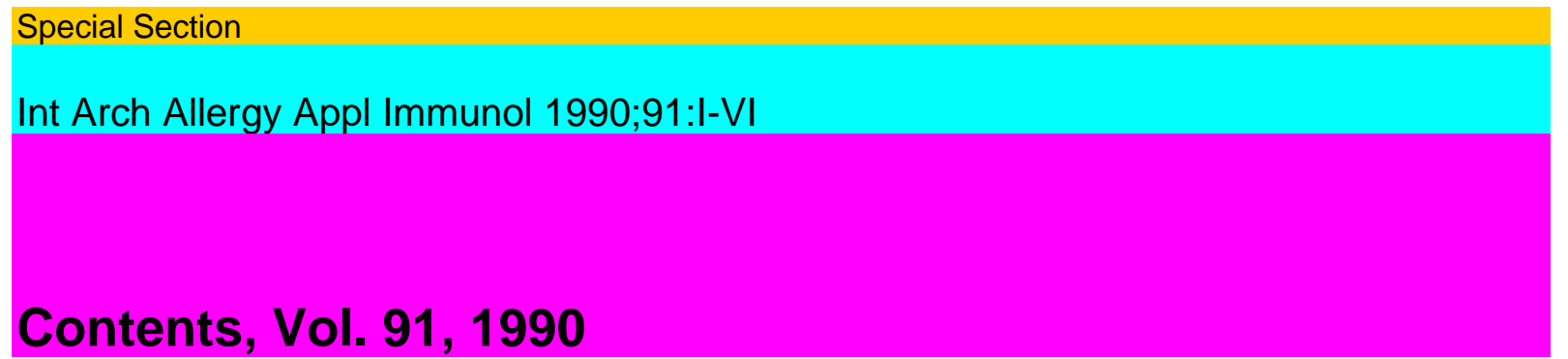

\title{
Vol. 91, 1990
}

International Archives

of Allergy and Applied

Immunology

Founded 1950 by D. Harley, P. Kallós, W. Löffler and F.W. Wittich

Continued by E.A. Brown (1952-1954), W. Kaufman (1955-1967), F. Hahn (1961-1972),

H.C. Goodman (1963-1975), R.R.A. Coombs (1955-1984), Z. Trnka (1972-1987),

P. Kallós (1950-1988)

Editors-in-Chief

J. Bienenstock, Hamilton L.Å. Hanson, Göteborg K. Kano, Tokyo F. Milgrom, Buffalo, N.Y. K. Rother, Heidelberg G.B. West, Epsom

$187 / 8 \mathrm{~K}$

$\mathrm{r}$

" $\psi$

$\mathrm{V}$

Contributing Editors

C.J. Abeyounis, Buffalo, N.Y.

N.F. Adkinson, Jr., Baltimore, Md.

St. Ahlstedt, Uppsala

B. Albini, Buffalo, N.Y.

E.L. Becker, Farmington, Conn.

N. Blomqvist, Göteborg

R. Burger, Berlin

A. Capron, Lille

C.G. Cochrane, La Jolla, Calif.

B. Diamant, Copenhagen

L. Edebo, Göteborg

S. Elsayed, Bergen

W.P. Faulk, Indianapolis, Ind.

J.C. Foreman, London

I. Glazer, Tel Aviv

H. Isliker, Lausanne

E.A. Kabat, New York, N.Y.

H. Milgrom, Denver, Colo.

M. Miyasaka, Tokyo

W. Müller-Ruchholtz, Kiel

P.L. Ogra, Buffalo, N.Y. Ö. Ouchterlony, Göteborg Z. Ovary, New York, N.Y. P. Perlmann, Stockholm R.E. Reisman, Buffalo, N.Y. G. Riethmüller, München M. Roitt, London U. Rother, Heidelberg G. Sandberg, Stockholm H.D. Schlumberger, Wuppertal A. Sehon, Winnipeg 
F. Shakib, Nottingham

O. Strannegård, Göteborg

G. Torrigiani, Geneve

J.L. Turk, London

E.R. Unanue, St. Louis, Mo. B.H. Waksman, New York, N.Y. G. Wick, Innsbruck H. Wigzell, Stockholm

KAI $\backslash$ GER

S. Karger $\square$ Medical and Scientific Publishers

Basel · München · Paris ' London · New York · New Delhi · Bangkok · Singapore · Tokyo · Sydney

Drug Dosage

The authors and the publisher have exerted every effort to ensure that drug selection and dosage set forth in this text are in accord with current recommendations and practice at the time of publication. However, in view of ongoing research, changes in government regulations, and the constant flow of information relating to drug therapy and drug reactions, the reader is urged to check the package insert for each drug for any change in indications and dosage and for added warnings and precautions. This is particularly important when the recommended agent is a new and/or infrequently employed drug.

All rights reserved.

No part of this publication may be translated into other languages, reproduced or utilized in any form or by any means, electronic or mechanical, including photocopying, recording, microcopying, or by any information storage and retrieval system, without permission in writing from the publisher or, in the case of photocopying, direct payment of a specified fee to the Copyright Clearance Center (see 'Information for Readers and Subscribers').

(C) Copyright 1990 by S. Karger AG, P.O. Box, CH- 4009 Basel (Switzerland) Printed in Switzerland by Buchdruckerei Basler-Zeitung AG, Basel

Contents Vol. 91,1990

No. 1

Original Paper

Studies of Chemotactic, Chemotactic Movement-Inhibiting and Random Movement-Inhibiting Effects of Interleukin-1

Alpha and Beta, Tumor Necrosis Factors Alpha and Beta and Interferon Gamma on Human Neutrophils in Assays $\backslash$ Using 'Sparse-Pore' Polycarbonate (Nuclepore) Mem branes in the Boyden Chamber Bignold, L.P.; Ferrante, A.; Haynes, D.R 1 Interleukin-2 Receptor Expression in Human Mast Cells and Basophils Maggiano, N.; Colotta, F.; Castellino, F.; Ricci, R.; Valitutti, S.; Larocca, L.M.; Musiani, P 8 Interactions of Hemopoietic Cytokines on Differentiation of HL-60 Cells. Nerve Growth Factor is a Basophilic Lineage-Specific Co-Factor Tsuda, T.; Switzer, J.; Bienenstock, J.; Denburg, J.A. .. 15

Allergen Entrapped in Liposomes Reduce Allergenicity and Induce Immunogenicity on Repeated Injections in Mice

Arora, N.; Gangal, S.V 22 
Histamine Receptors on Leukocytes Are Expressed Differently in vitro and ex vivo

Leino, L.; Lilius, E.-M 30

Increased Autoreactive T Cell Frequency in Tuberculous Patients

Del Gallo, F.; Lombardi, G.; Piccolella, E.; Gilardini

Montani, M.S.; Del Porto, P.; Pugliese, O.; Antonelli, G.;

Colizzi, V 36

Immunoreactive Leukotrienes in Nettle Plants (Urtica urens)

Czarnetzki, B.M.; Thiele, T.; Rosenbach, T 43

Serological Analysis of Experimental Autoimmune Thyroiditis

in the Buffalo Strain Rat

Cohen, S.B.; Weetman, A.P 47

Correlation between Atopy and Gm Allotypes

Oxelius, V.-A 54

Gm Allotype Genes and Gene Dosage Affecting Both IgG Sub

class and IgE Levels in Atopic Patients

Oxelius, V.-A 58

Immunogenicity Testing of Food Proteins: in vitro and in vivo Trials in Rats Steinmann, J.;

Wottge, H.-U.; Müller-Ruchholtz, W. . . 62

Endothelial Cells Modulate Both T-Cell Dependent and T-Cell-Independent Plaque-Forming

Cell Generation in vitro

Teitel, J.M.; Shore, A.; McBarron, J.; Leary, P.L.; Schia-

vone, A 66

Biological and Immunological Properties of Sugi Basic Pro-

tein-Pullulan Conjugate. II. Is the Reduced Ability to Elicit

the Arthus Reaction Based on the Poor Activation of Com

plement by Immune Complex Consisting of Anti-Sugi

Basic Protein and Sugi-Basic Protein-Pullulan?

Usui, M.; Taniguchi, Y.; Ando, S.; Kurimoto, M.; Matu-

hasi, T 74

Activation of Kallikrein-Kinin System in Human Plasma with

Purified Serine Protease from Dermatophagoides farinae

Takahashi, K.; Aoki, T., Kohmoto, S.; Nishimura, H.;

Kodera, Y.; Matsushima, A.; Inada, Y 80

Enhancement of Antigen-Induced Bronchoconstriction in the

Guinea Pig after Intravascular Complement Activation

with Cobra Venom Factor

Regal, J.F 86

Regulation of in vivo Expression of Fc Receptors for IgE (Fc\&R) on Murine Lymphocytes. I.

Detection of FceR Lymphocytes by Flow Cytometry Kiniwa, M.; Yangihara, Y.; Watanabe, N.;

Tasaka, K. . 95

Enhancing Effect of Clq on IgG Monoclonal Antibody Binding to Hapten Hamada, A.;

Watanabe, N.; Azuma, T.; Kobayashi, A. .103

Short Communications

Mouse Autoantibodies Bind to a Phospholipase-C-Sensitive

Structure on Red Blood Cells 
Hardy, S.J.; Cox, K.0 108

Basophil Releasability in Human Hydatidosis

Aceti, A.; Celestino, D.; Caferro, M.; Teggi, A.; Pennica,

A.; Adriani, E.; Grilli, A.; Paparo, S.; Leri, O.; De Rosa, F.;

Sebastiani, A Ill

IV

Contents

No. 2

Original Paper

Fibronectin Levels in Plasma after Platelet-Activating Factor

Inhalation

Nabe, M.; Miyagawa, H.; Hopp, R.J.; Agrawal, D.K.;

Bewtra, A.K.; Townley, R.G 113

Isolation of cDNA Coding for the Major Mite Allergen Derp II

by IgE Plaque Immunoassay

Chua, K.Y.; Doyle, C.R.; Simpson, R.J.; Turner, K.J.;

Stewart, G.A.; Thomas, W.R 118

Expression of Dermatophagoides pteronyssinus Allergen, Der

p II, in Escherichia coli and the Binding Studies with

Human IgE

Chua, K.Y.; Dilworth, R.J.; Thomas, W.R 124

Characterization of Allergenic Components in Sap Extract

from the Weeping Fig (Ficus benjamina)

Axelsson, I.G.K.; Johansson, S.G.O.; Larsson, P.H.; Zetter-

ström, $0 \quad 130$

Characterization of Four Major Allergens of Hen Egg-White

by IEF/SDS-PAGE Combined with Electrophoretic Transfer and IgE-Immuno-autoradiography

Holen, E.; Elsayed, S 136

Blood Histamine Levels in HIV-1-Infected Infants and Children

Burtin, C; Blanche, S.; Galoppin, L.; Merval, R.; Griscelli,

C; Scheinmann, P 142

Immunopathological Response of C57BL/6 and $\mathrm{C} 3 \mathrm{H} / \mathrm{HeN}$

Mice to Aspergillus fumigatus Antigens

Kurup, V.P.; Choi, H.; Resnick, A.; Kalbfleisch, J.; Fink, J.N. 145 A Contiguous Network of

Dentritic Antigen-Presenting Cells

within the Respiratory Epithelium

Holt, P.G.; Schon-Hegrad, M.A.; Oliver, J.; Holt, B.J.;

McMenamim, P.G 155

Influence of Glutathione Conjugation on the Immunogenicity

of Dinitrophenyl Derivatives in the Rat

Tingle, M.D.; Clarke, J.B.; Kitteringham, N.R.; Park, B.K. 160 Effect of Age, Culture Medium and Lymphocyte Presence on

Ascorbate Content of Peritoneal Macrophages from Mice

and Guinea Pigs during Phagocytosis

Hernanz, A.; Collazos, M.E.; de la Fuente, M 
Histological Study of Mast Cells in the Actively Sensitized Guinea Pig Lung and after Challenge: Effect of a Corticosteroid

Bachelet, C.-M.; Bernaudin, J.-F.; Fleury-Feith, J 171

Glucocorticoid-Induced Appearance of the Macrophage Sub

type RM 3/1 in Peripheral Blood of Man

Zwadlo-Klarwasser, G; Bent, S.; Haubeck, H.-D.; Sorg, C;

Schmutzler, W175

Endogenous Histamine in Immune Inflammation in 6-Day-

Old Air Pouch of Facsimile Synovium

Sin, Y.M.; Ang, L.N 181

Immune Response to Blomia kulagini and Dermatophagoides

pteronyssinus in Sweden and Brazil

van Hage-Hamsten, M.; Machado, L.; Barros, M.T.;

Johansson, S.GO 186

Reactivity of Mast-Cell-Bound IgE Idiotypes with Anti-Idio-typic Antibody: Mediator Release or Inhibition of Antigen-Induced Mediator Release?

Wheeler, A.W.; Deards, M.J.; Hickman, B.E.; Spackman,

V.M.; Johansson, S.G.0 192

Further Characterization of Surface Membrane Structures

Expressed on Human Basophils and Mast Cells

Valent, P.; Majdic, O.; Maurer, D.; Bodger, M.; Muhm, M.;

Bettelheim, P 198

Short Communications

Abolished Net Output of Lymphocytes from the Spleen after

Immunization with Salmonella typhi $\mathrm{H}$

Sandberg, G 204

Interleukin-1 Release by Alveolar Macrophages in Asthmatic

Patients and Healthy Subjects

Pujol, J.-L.; Cosso, B.; Daurès, J.-P.; Clot, J.; Michel, F.-B.;

Godard, P 207

Sequential Analysis of Histamine Release and Intracellular

$\mathrm{Ca} 2+$ Release from Murine Mast Cells

Tasaka, K; Sugimoto, Y.; Mio, M 211

Further Thoughts on Mast Cells, Calcium Channels and Histamine Release

West, GB 214

!

Fig. 1. Light micrographs of nasal mucosa biopsy specimens, $a, b$ Seemingly normal nasal mucosa (a) from a 'healthy control' subject. At higher magnification (b), it becomes obvious that necrotic epithelial cells may be recognized and that cytoplasmic blebs extend from the luminal surface. Note the many blood vessels along the basement membrane, c Low-power micrograph demonstrating the variations in the epithelium, being metaplastic to the right, pseudostratified in the center, and discontinuous at the left margin. Patient with RAOM. d A cluster of epithelial cells bulges from the gland duct in the center, seemingly in an attempt to restore the adjacent injured epithelium. 'Healthy control' subject, e, f Low-power micrograph (e) of a biopsy specimen from a patient with RAOM, demonstrating extensive epithelial damage and even some 
denudation as well as many blood vessels. At higher magnification (f), it can be recognized that capillaries almost penetrate the thin basement membrane and approach residing epithelial cells, $g$ Numerous vascular loops extend into the nasal epithelium which is predominantly metaplastic and form a continuous covering. Gland ducts are seen in the lamina propria. Patient with RAOM. $\mathrm{h}$ Remnants of the nasal epithelium are seen to the left, while the basement membrane is denuded to the right. Blood vessels approach the thickened basement membrane. 'Healthy control' subject, i Scattered goblet cells may be identified by their red color. Note the discontinuity in the epithelial lining in the center. The glands are separated by collagen bundles. 'Healthy control' subject, j Low-power micrograph of nasal mucosa biopsy specimen from a 'healthy control' subject. The epithelium to the left is somewhat irregular, but pseudostratified and containing several goblet cells. The epithelial covering in the center is partly necrotic and lacking to the right. Note the fibrosis in the lamina propria to the right. 'Healthy control' subject, k Numerous goblet cells may be recognized by their red staining at various depths in the discontinuous epithelial lining. Note the irregular basement membrane. RAOM patient. 1 Scattered red goblet cells are seen in the metaplastic nasal epithelium. The epithelial lining is continuous, but hides increased intercellular spaces. RAOM patient, $\mathrm{m}$ Red-stained goblet cells and inflammatory cells are seen in the depth among the somewhat irregular, mainly pseudostratified epithelium. Several glands in the lamina propria, separated by collagen bundles. 'Healthy control' subject, $\mathrm{n}$ Goblet cells and inflammatory cells may be recognized in the metaplastic nasal epithelium from a RAOM patient. Note the irregular basement membrane and the collagen bundles in the lamina propria. $\mathrm{O}$ Metaplastic epithelium covering the tortuous basement membrane and blood vessels. A microabscess to the top right. A cluster of cells in the lamina propria gland to the right appears necrotic. 'Healthy control' subject, $p$ The superficial metaplastic epithelial cells may form a continuous lining that covers the extended extracellular spaces recognized among the few cells. The basement membrane is irregular and is bordered by blood vessels and interposed cells. Seromucous glands in the lamina propria (to the left). RAOM patient.

\section{Contents}

$\mathrm{V}$

No. 3

Original Paper

Mapping of Epitopes on Poa $p$ I and Lol p I Allergens with

Monoclonal Antibodies

Lin, Z.; Ekramoddoullah, A.K.M.; Jaggi, K.S.; Dzuba-

Fischer, J.; Rector, E.; Kisil, F.T 217

, Western Blot Analysis of Water-Soluble Wheat Flour (Triticum vulgarís) Allergens

Pfeil, T.; Schwabl, U.; Ulmer, W.T.; König, W

Recombinant Neutral Endopeptidase Attenuates Substance

P-Induced Plasma Extravasation in the Guinea Pig Skin

Rubinstein, I.; Iwamoto, I.; Ueki, I.F.; Borson, D.B.;

Nadel, J.A 232

Effects of Toxocara canis Infection on Hemopoietic Stem Cells

and Hemopoietic Factors in Mice

Higa, A.; Maruyama, H.; Abe, T.; Owhashi, M.; Nawa, Y. 239 Release of Platelet-Activating

Factor in Systemic Lupus ery- 
thematosus

Tetta, C; Bussolino, F.; Modena, V.; Montrucchio, G.;

Segoloni, G.; Pescarmona, G.; Camussi, G 244

Morphological Basis for Impaired Protective Efficiency by the

Nasal Mucosa in Infants with and without Recurrent Acute

Otitis media: A Light and Electron Microscopy Study

(With 2 color plates)

Jørgensen, F.; Hansson, H.-A 257

Grass Pollen Allergens: Detection on Pollen Grain Surface

Using Membrane Print Technique

O’Neill, P.M.; Singh, M.B.; Knox, R.B 266

Antigen-Induced Mucosal Damage and Restitution in the

Small Intestine of the Immunized Rat

D'lnca, R.; Ramage, J.K.; Hunt, R.H.; Perdue, M.H. . . 270 Antigenic and Allergenic

Characterization of the Enzymes

Alcalase and Savinase by Crossed Immunoelectrophoresis

and Crossed Radioimmunoelectrophoresis

Arlian, L.G.; Vyszenski-Moher, D.L.; Merski, J.A.; Ritz,

H.L.; Nusair, T.L.; Wilson, E.R 278

Relationship between Alterations in Atrial and Ventricular

Histamine Content and Cardiac Function during Cardiac

Anaphylaxis of Isolated Guinea Pig Hearts

Heller, L.J.; Regal, J.F 285

Induction of Suppressor Cell Activity by Cyclosporin A and/or . Uremic Serum in Normal versus

Uremic Peripheral Blood Mononuclear Cells

Modai, D.; Bermann, S.; Cohen, D.; Amit, M.; Cohn, M.;

Weissgarten, J.; Averbukh, Z 291

Antibodies from Patients with Rheumatoid Arthritis and Juvenile Chronic Arthritis Analyzed

with Core Histone Synthetic Peptides

Tuaillon, N.; Muller, S.; Pasquali, J.-L.; Bordigoni, P.;

Youinou, P.; Van Regenmortel, M.H.V 297

T Cell Receptor Variable Gene Expression: Analysis in Ragweed-Sensitive Patients during

Allergen Exposure Burton, D.A.; Sheperd, G.M.; Siskind, G.W.; Posnett, D.N. 306

Aeroallergen-Induced Immediate Asthmatic Responses and Late-Phase Associated Pulmonary

Eosinophilia in the Guinea Pig: Effect of Methylprednisolone and Mepyram-ine (With 2 color

plates)

Chand, N.; Hess, F.G.; Nolan, K.; Diamantis, W.; McGee,

J.; Sofia, R.D 311

Antigen-Restricted Antigenic Competition Induced by 2,4-Dinitrochlorobenzene: Association with Depression of Lymphocyte Proliferation Kimber, I.; Bentley, A.N.; Ward, R.K.; Baker, D.;

Turk, J.L. 315

Hanganutziu-Deicher Antigen as a Possible Target for Immu-notherapy of Melanoma Nakarai,

H.; Chandler, P.J.; Kano, K.;Morton, D.L.;Irie, R.F. 323

VI

Contents

No. 4 
Original Paper

Phenotypic Analysis of Lymphocytes Involved in Major Histo-

compatibility Complex Unrestricted Cellular Cytotoxicity

in Patients with Alcoholic Cirrhosis

Müller, C; Wolf, H.; Göttlicher, J.; Eibl, M.M 329

Immunogenicity of Amodiaquine in the Rat

Clarke, J.B.; Maggs, J.L.; Kitteringham, N.R.; Park, B.K. 335

Identification of a 'Disease-Associated' Antigen in Pigeon

Breeder's Disease by Western Blotting

de Beer, P.M.; Bouic, P.J.; Joubert, J.R

343

Expression and Distribution of la Antigen in the Murine Small

Intestine. Influence of Environment and Cholera Toxin

Wilson, A.D.; Bland, P.W.; Stokes, C.R 348

Human Recombinant Lymphokines and Cytokines Induce Pulmonary Eosinophilia in the Guinea

Pig which Is Inhibited by Ketotifen and AH 21-132

Kings, M.A.; Chapman, I.; Kristersson, A.; Sanjar, S.;

Morley, J. 354

Isolation and Characterization of a cDNA Clone Encoding an IgE-Binding Protein from

Kentucky Bluegrass (Poa praten-sis) Pollen

Mohapatra S.S.; Hill, R.; Astwood, J.; Ekramoddoullah,

A.K.M.; Olsen, E.; Silvanovitch, A.; Hatton, T.; Kisil, F.T.;

Sehon, A.H 362

Inhibition of IgE-Mediated N-Acetylglucosaminidase and Se

rotonin Release from Rat Basophilic Leukemia Cells

(RBL-2H3) by Tenidap: A Novel Anti-Inflammatory

Agent

Conklyn, M.J.; Kadin, S.B.; Showell, H.J 369

Rhesus Monkey Airway Responses to Substance P1

Patterson, R.; Harris, KE 374

Histamine Release from Human Basophils by the Insect Aller

gen Chi 11

Baur, X.; Mazur, G.; Jarosch, B 380

The Airway Epithelial Lining in Guinea Pigs Is Intact

Promptly after the Mucosal Crossing of a Large Amount of

Plasma Exudate

Luts, A.; Sundler, F.; Erjefált, I.; Persson, C.G.A 385

Close Relationship between Neopterin and Beta-2-Microglo-

bulin Levels in Intravenous Drug Abusers

Lin, R.Y.; Nygren, E.; Valinsky, J.; Lorenzana, F.G.;

Ralph, $\mathrm{H} \quad 389$

Induction of Interleukin-1-Beta Release from Human Mono-

cytes by Cotton Bract Tannin

Vuk-Pavlovic, Z.; Rohrbach, M.S 394

Degranulation of Mast Cells in the Trachea and Bronchi of the

Rat following Stimulation of the Vagus Nerve

Kiernan, J.A 398 
Sequential Appearance of Basophils and Mast Cells from $\mathrm{Hu}$

man Bone Marrow in Long-Term Suspension Culture

Bressler, R.B.; Friedman, M.M.; Kirshenbaum, A.S.; Irani,

A.-M.A.; Schwartz, L.B.; Metcalfe, D.D 403

Isolation and in vitro Translation of mRNA from Inflorescences of Parietaria judaica

Scotto d'Abusco, A.; Lo Schiavo, F.; Oreste, U.; Coscia,

M.R.; Santonastaso, V.; Sacerdoti, G.; Ruffill·i, A 411

Monoclonal Antibodies to Proteins from Cocksfoot Grass (Dactylis glomerata) Pollen: Isolation and N-Terminal Sequence of a Major Allergen

Walsh, D.J.; Matthews, J.A.; Denmeade, R.; Maxwell, P.;

Davidson, M.; Walker, M.R 419

Naturally Occurring IgG-Antibody-Like Substance Reacting

with Quaternary Ammonium Group and Neuromuscular

Blockers: A Common Finding in Humans and Other Spe

cies?

Assem, E.S.K 426

IgG-Class Insulin Autoantibodies and Autoimmune Thyroid Disease Ng, W.Y.; Thai, A.C; Lui, K.F.; Yeo, P.P.B.; Cheah, J.S. 431

Short Communication

Induction of HLA Class I Surface Expression Recruits Low-

Affinity Cytolytic T Lymphocytes

Mentzer, S.J.; Burakoff, S.J.; Barbosa, J.A 437

Author Index 441 